\title{
Fetö Terör Örgütü Hakkında Emniyet Ve Diyanet Teşkilatının 15 Temmuz Sonrası Hazırladıkları Çalışmaların Sosyolojik Analizi
}

\section{The Sociological Analysis of the Works After Prepared by General Directorate of Police and Precidency of Religious Affairs After 15 July on the Feto Terrorist Organization}

\section{Dr. Ibrahim Yüksel ${ }^{1}$}

Başvuru Tarihi: 31.10.2019

Kabul Tarihi: 02.12.2019

\section{Öz}

Fetullahçı Terör Örgütü (FETÖ), ülkemiz için en büyük tehditlerden biri olduğunu 15 Temmuz Darbe girişimiyle ortaya koymuştur. Bütün terör örgütleri etkin olduğu bölgeler için tehdittir. Ancak FETÖ’nün diğer terör örgütlerinden farklı olarak sosyo-ekonomik, sosyo-psikolojik, sosyopolitik, güvenlik ögelerini içinde barındırması, kripto elemanlarla uyuyan hücreler şeklinde yapılanması, diğer terör örgütleri ve dış istihbarat birimleriyle işbirliği yapma gibi özellikleri onu daha büyük bir tehlike haline getirmektedir. FETÖ yaklaşık 40 ylllık bir çalışmayla toplumun dini, sosyo-psikolojik, sosyo-ekonomik alanlardaki ihtiyaçlarını eğitim, hayır işleri gibi maskelerle perdeleyerek çok ciddi bir destek elde etmiştir. Bu durumun oluşmasında hiç şüphesiz devlet kurumlarının boş bıraktığı alanları çok hızlı bir şekilde doldurmalarının da bu sürece gelinmesinde etkileri olduğu söylenebilir. Bu çalışma da darbe girişimi sonrası FETÖ ve benzeri yapıları anlamak ve yeni FETÖ'lerin ortaya çıkışını engellemek için devlet kurumlarının yaptıkları çalışmaların analizi yapılacaktır. FETÖ benzeri yeni yapıların ortaya çıkışını önlemek için devletin ve sivil toplum örgütlerinin toplumsal hayatta boşluk bırakmadan ilgili boşlukların doldurulmasina bağlı olduğu söylenebilir.

Anahtar Kelimeler: FETO, Terör Örgütü, Örgütlenme, 15 Temmuz

\begin{abstract}
Abstact
The Fetullah Terrorist Organization (FETO) appeared to be the one of the biggest threats for our country after the 15 July unsuccessful coup appemt. All terrorist organizations are a threat to the regions where they are active. However, FETO, unlike other terrorist organizations, its features such as, socio-economic, socio-psychological, socio-political, having security elements within the structure, the formation of crypto elements as sleeping cells, cooperating with other terrorist organizations and foreign intelligence services make it even a greater danger. With almost 40 years of work, FETO has gained a very serious support by covering the needs of society in religious, sociopsychological, socio-economic areas by making such as education and charity. No doubt, it can be said that, for the occurence of this situation, their filling vacancies very quickly which are left by
\end{abstract}

\footnotetext{
1 Atatürk Anadolu Lisesi Rehber Öğretmeni, Antalya/Kepez, iyuksel56@hotmail.com, ORCID ID: 0000-0001-5173-4387
} 
the State Instutions has effects. In this study, the works of government institutions after the coup attempt which were done to understand the structures of FETO and similar structures and to prevent the emergence of new FETOs will be analyzed. It can be said that, in order to prevent the emergence of new structures similar to FETO depends on the State's and NGOs' filling in the gaps without leaving no space in social life.

Keywords: FETO, Terrorist Organization, Organization, 15 July

\section{Giriş}

Türkiye Cumhuriyetini kuran kadrolar, Osmanlidan kalan kurumların tasfiye edilmesi, yerine yeni kurumların oluşturulması ve yeni devletin kendi ideolojisini yerleştirme çabaları sırasında radikal reformlar gerçekleştirmişlerdir. Bu reformlar geçmiş dönemlerde toplumsal ilişkilerin düzenlenmesinde oldukça etkili olan dinin toplumsal hayattan soyutlanmasına din ve devlet işlerinin birbirinden ayrılması şeklinde tezahür etmiştir. Devletin dini dışlaması, din eğitiminin engellenmesi, dini kurumların vakıfların vs. kapatılması gibi nedenlerle dini gruplar da doğal olarak devlet kurumlarında kendilerine yer bulamamışlardır. Bu dinin ve dini grupların devlet kurumlarından dışlanması sonucu oluşan boşluk herhangi bir resmi yapı tarafından doldurulmamış/doldurulamamıştır. Oluşan bu boşluğu ise dışlanan dini yapılar gayri resmi yollardan, denetimsiz, şeffaflıktan uzak bir biçim şekilde doldurmaya başlamışlardır.

Oysa insanoğlu diğer canlılardan faklı olarak maddi ihtiyaçlarının yanında manevi ihtiyaçlara da sahiptir. Tarihi süreçte da bu manevi ihtiyaç dinler aracilığıyla karşılanmıştır. Din insanlık tarihi kadar eski bir olgu olduğu için geleceğinin de insanlık tarihiyle paralel olacağı söylenebilir. Çünkü gelecekte insanların dini toptan terk etmesini sağlayacak bir neden görünmemektedir. Ayrıca din, tarihin hiçbir döneminde hayattan kopuk, vicdanlara hapsedilmiş kuru bir inanç sistemi olmamıştır. Aksine, hemen her devirde insanların hayat tarzlarına, sosyal kurumlarına, ticaret hayatlarına, aile hayatlarına kısaca hayatın her alanını şekillendirmiştir. Bu nedenle dinin devlet kurumlarıyla ilişki içerisine girmesi kaçınılmaz olmaktadır (Kaya, 2012, s.3).

Toplumun ihtiyaçlarını iyi analiz eden bu gruplar bu ihtiyaçları karşlayacak mekanizmalar kurarak toplumsal alandaki varlıklarını güçlendirmiş̧lerdir. Bu yapılardan birisi olan bir eğitim ve hizmet hareketi olarak kendini topluma kabul ettiren yapılardan birisi de önceleri Cemaat, Gülen Hareketi, Hizmet Hareketi vs. adlarıyla anılan yapıdır. Fethullah Gülen önderliğinde kurulan bu yapı, dini gruplara yönelik baskının sosyo-psikolojik etkilerini kendi çıarlarına uygun bir şekilde kullanmış denetimden, kontrolden uzak olan yapısını daha da ezoterik bir yapıya evrilerek dini bir grup olmaktan çıkıp terör örgütüne dönüşmüştür (Tunç ve Atılgan, 2017, s.81). Bu çalışma da cemaat olarak ortaya çıkışından silahlı terör örgütüne dönüşmesine varana kadar örgütün tarihine kısaca değinilecek esas olarak ise 15 Temmuz Darbe girişimi 
sonrası FETÖ ile mücadele konusunda Diyanet ve Emniyet Teşkilatının hazırladığı raporların sosyolojik olarak incelenmesi amaçlanmaktadır.

Çalışmada devletin yargı organlarınca resmi olarak ifade edilen Fetullahçı Terör Örgütü yerine göre FETÖ kısaltması veya örgüt ifadesi kullanılmıştır. Çalışmaya temel olarak Polis Akademisinin “Yeni Nesil Terör FETÖ’nün Analizi” ve Diyanet İşleri Başkanlığının hazırladığı "FETÖ Din İstismarının Arkasına Gizlenen Terör Örgütü" başlıklı eserleri alınmış özellikle FETÖ vb. yapılarla mücadele ve yenilerinin oluşmaması için yapılan öneriler incelemeye alınmıştır.

\section{Türkiye'de Din-Devlet Ilişkileri ve Fetö’nün Tarihine Kısa Bir Bakış}

Cumhuriyet'in ilanıyla birlikte Osmanlıdan radikal bir şekilde kopuşun sonucu yeni bir devlet, toplum ve ideoloji yaratma çalışmaları hız kazanmıştır. Bu çalışmalar sırasında özellikle dindevlet işlerinin ayrılmasını öne alan katı laiklik anlayışı sonucu dinin toplumsal hayattan dışlanması, dini kurumların kapatılması, din eğitiminin engellenmesi vb. nedenlerle dini yapılar (tarikatlar, cemaatler vs.) yer altına inmişler, içe kapanmışlar ve uzun süren bir sessizliğe bürünmüşlerdir. Bu durum çok partili hayata geçilmesiyle dini alanda başlayan kısmi rahatlama süreciyle beraber tarikat, dini cemaat vb. yapılarda bir hareketlilik başlamaya ve tekrar ortaya çımaya başlamışlardır.

Din insanların hayatlarında son derece önemli rollere sahip temel toplumsal kurumlardan biri olmakla birlikte özellikle Aydınlanma'dan bu yana çok farklı türlerde rasyonel yorumların oldukça ağır bir saldırısı altında kalmıştır. L. Feuerbach, K. Marx gibi düşünürler dinin bütün kötülüklerin nedeni, toplumların geri kalmasına neden olan, onları bunalımlara ve buhranlara sürükleyen bir olgu olduğunu ifade ederler (Özdalga, 2007, s.15). Dine bu olumsuz bakışın yanında "dinlerin, bireyleri ve toplumları bunalım ve buhranlardan çıkaran birer sı̆̆ınak, birer liman, kalpsiz dünyanin kalbi ve acı çeken kitlelerin bir afyonu olarak görülebildiklerini unutmamak gerekir" (Arslan, 2012, s. 424) şeklinde dine olumlu yönden bakış açıları da söz konusudur.

Din konusunda farklı yaklaşımlarla birçok tanım yapılmıştır. Çağdaş Filozof L. Kolakowski; Dinin kabul edilebilir farklı tanımları olduğunu ancak dinin dünyevi (toplumsal ve psikolojik) ihtiyaçların karşılanmasında bir aracıdan başka bir şey değildir anlayışının doğru olmadığını, bunların ampirik ifadeler olduğunu, peşinen bir tanımın parçaları olarak kabul edilemeyeceğini ifade eder. Ona göre halkın dini söylemde anlatmak istediği şey, açıkça anlatmak istediği şeydir kabulüne dayanır ve dinin toplumsal olarak kurulmuş ebedi gerçeklik olduğu inancı olduğu, yani iddia edilen ilahi gerçeklik olduğu gibi kabul edilir ve bu deneyimlerin ifadeleri ise sosyolog veya antropoloğun normal diline aktarılmadan ciddiye alınır (Özdalga, 2007, s.20).

Dinin resmi, kurumsallaştırılmış bir toplumsal gerçekliğinin olmasının yanında binlerce yıldır insanoğlunun en temel en derin insani varoluşsal sorgulamalarının ve sorunlarının bir ifadesi olarak şekli değişmiş olsa da varlığını bir şekilde devam ettireceğinin bir kanıtı olarak günümüzde de tartışmaya hala devam edilmesi açık bir kanıtı olarak görülebilir. 
Cumhuriyet yönetimi, Osmanlı toplumunu bir arada tutan önemli unsurlardan biri olan dini, siyasal bir güç olmaktan çlkartıp onu sadece vicdanlarda yaşanan bir inanç haline getirmeyi amaçlamıştır (Duman, 2010:294). Bu durum elbette yüzyıllardır toplumsal ilişkilerin düzenlenmesinde oldukça etkili olan dinin birdenbire ortadan kalkmasına neden olmamıştır. Zaman zaman küçük çatışmalara neden olsa da büyük çaplı bir çatışmadan kaçınılarak dini grupların kendilerini gizlemelerine ve eylemlerine bu şekilde devam etmelerine neden olmuştur. Özellikle din devlet işlerinin ayrılması, dinin etkisinin azaltılması için halifeliğin kaldırılması, Tevhid-i Tedrisat Kanunuyla medreselerin kapatılıp, tüm eğitim kurumlarının Maarif Vekaletine bağlanması, ezanın Türkçeleştirilmesi, camilere sıraların yerleştirilmesi çalı̧maları, din eğitimine eğitim sisteminde neredeyse hiç yer verilmemesi gibi durumlarla beraber düşünüldüğünde vatandaşta oluşan dini bilgi ihtiyacını ve hassasiyetini elbette kullanmak isteyen yapıların ortaya çıkacağı son derece açıktır. (Tunç ve Atılgan, 2017, s. 82).

Oysa dinin etkisini azaltarak katı laik politikalarla demokratikleşmenin sağlanacağ anlayışı doğru bir bakış açısı olmamıştır. Kapatılan ve toplumda karşılığı olan ihtiyaçları karşılayan kurumların yerine onun fonksiyonlarını icra edebilecek yeni kurumların oluşturulmaması bu alanda ciddi bir boşluğun oluşmasına neden olmuştur. Oysa bir çok düşünür gibi örneğin Habermas'da (2006) toplumların ne kadar ilerlerse ilerlesin ne kadar seküler bir anlayışa sahip olurlarsa olsunlar geleneksel yapıların ve grupların varlıklarını ve geçerliliklerini sürdürebildiklerini ifade etmiştir.

Tarikat ve cemaatler, sosyal alanda insanların dini hayatlarını sürdürmelerini sağlayacak din adamlarının yetiştirmesini sağlamak, halkın dini kültürünün devamlılığına katkı yapmak ve kapatılan dini eğitim kurumlarından ortaya çıkan boşluğu doldurmak amacıyla yeraltına inerek, içe kapanarak, uzun süreli bir sessizlik dönemiyle beraber denetimden, şeffaflıktan uzak bir şekilde faaliyetlerine devam etmişlerdir (Ayık, 2016, s.72; Arslan, 2012, s.10).

Çok partili hayata geçilmesi ve 1950 'de Demokrat Parti'nin iktidara gelmesiyle 1932'den beri Türkçe okunan ezan Arapça okunmaya başlanmış, hac ibadetine yönelik kısıtlamalar kaldırılmış, türbeler de yeniden açılmıştır. Eğitim alanında ise 1953-1956 arasında lise düzeyinde eğitim veren İmam Hatip okulları açılmıştır (Mardin, 2012, s.72). Çok partili hayatla birlikte Demokrat Partinin, cumhuriyetinden kuruluşundan itibaren uygulanan katı laik uygulamaları yumuşatması ve kısmen bir özgürlük ortamı sağlamasıyla dini cemaatlerin görünürlükleri artmaya başlamıştır. Ancak cumhuriyetin ilk ylllarının psikolojik etkilerinden dolayı cemaatler tam bir şeffaflıktan genellikle kaçınmışlar ve günümüzde de bu durum büyük oranda aynen devam etmektedir.

Türkiye'deki önemli dini hareketlerden biri olan Said Nursi tek parti döneminin ve bu dönemin modernleşme çabalarının sancılı süreçlerinde toplumsal muhalefetin ana aktörlerinden biri olmuştur. Daha sonra gelenekselleşen bu temsil edişin üstlendiği barışçı ve sağlıklı toplumsal muhalefet, öncelikli olarak dini veya siyasi bir muhalefet olmaktan öte, toplumun ihtiyaçlarını ve arayışlarını gözeten bir muhalefet olarak algılanmıştır. Said Nursi özellikle Tek Parti döneminde 'Şeytandan ve siyasetten Allah'a sığınırım' diyerek siyasetten uzak kalsa da hareket 
özellikle çok partili hayatla kurulan Demokrat Partiye ve başındaki lider değişse de ehveni şer tabiriyle sürekli destek olmuştur (Arslan, 2012, s.13). Said Nursi hareketi FETÖ’nün çıkış noktası olduğu için önemli bir hareket olup, FETÖ lideri de çeşitli söylemlerinde 'Cebrail parti kursa desteklemem' gibi ifadeler kullanmasına rağmen kurulduğundan beri mevcut siyasi partilerle çok sıkı ilişkiler içine girdiği, konjektürel olarak bazılarını destekledikleri siyasete doğrudan müdahil oldukları özellikle son 3-4 seçimdir çok açık bir şekilde görülmektedir.

1970'lerden sonra Kur'ân-Kurslarının resmiyet kazanması ve İmam Hatip Liselerinin sayılarının artması ile cemaat liderleri ile din görevlileri arasında ayrılıklar oluşmuştur. Gelişmelerin aleyhlerinde ilerlediğini gören cemaatler, hem resmi olarak din eğitimi veren kurumlarında kadrolaşmaya çalışmışlar hem de kendi faaliyet alanlarını farklılaştırmaya ve çeşitlendirmeye çalışmışlardır. Bu değişimlerine rağmen yine de genel anlamda eğitim sektörü çerçevesinde kalmışlardır. Özellikle ortaokul, lise ve üniversitelerde eğitim gören öğrencilere ev, pansiyon, yurt gibi çeşitli şekillerde barınma imkanları sağlayarak öğrencilerin sosyal ihtiyaçlarına cevap veren cemaatler, yardım veya burs gibi isimlerle ayni ve nakdi desteklerle de öğrencilerin sosyoekonomik ihtiyaçlarını karşılamışlardır (Sarıkaya, 1998, s.97).

FETÖ ve diğer cemaat adı altındaki yapılanmalar özellikle son yıllarda İmam-Hatip Liselerinin sayılarının artması, diğer okullarda da müfredata din eğitimine yönelik derslerin (Kur'ân Kerim, Peygamber Efendimizin Hayatı gibi...) konması, Diyanetin yaz Kur'ân kurslarında dini eğitimler vermeye başlaması, Diyanetin 4-6 yaş çocuklar için Anaokulları açması, Diyanet Radyo ve Diyanet TV’nin yayınlara başlamalarını çok sert bir şekilde eleştirmişlerdir.

Yine Kredi Yurtlar Kurumunun öğrenci kapasitesinin artırılmasına yönelik çalı̧̧malar, din eğitimi konusunda son yıllarda atılan adımlar da bu yapıları rahatsız eden önemli gelişmelerden biri olarak görülmektedir. Hatta adı güya dini cemaat olan bu yapılar bu eleştirileri katı laik kesimden daha ağır bir şekilde yapmaktan çekinmemişlerdir. Bu eleştirilere çalıştı̆̆ımız kurumlarda şuan FETÖ'den ihraç olan kişilerden veya başka cemaat görüntüsündeki yapılara mensup üyelerden defalarca rastlanılmıştır. Çünkü halkın dini bilgi ihtiyacının resmi yollardan karşılanması, çocuklarının eğitim-öğretim yılları boyunca devlet kurumlarının güvencesinde kalabilmesi bu tür yapıların vatandaşı istismar edeceği alanları sınırlayacağının farkındadırlar. Özellikle dersanelerin kapatılması konusunun konuşulmaya başladığı günlerde FETÖ’nün tüm gücüyle hükümete yönelik savaşa giriştiği, MİT başkanının ifadeye çağrılması, MİT Tırlarının Durdurulması, 17-25 Aralık Operasyonları ve en son 15 Temmuz Darbe girişimi vb. olaylar birlikte düşünüldüğünde durum daha net bir şekilde anlaşılacaktır.

İşte bu yapılardan biri olan FETÖ'nün temelleri de 1962-1963 yılları arasında Erzurum 'Komünizmle Mücadele Derneği'nin kurucusu ve aktif çalışanı olarak Fetullah Gülen tarafından atılmıştır (Özdalga, 2007, s.251). Sonrasında vaiz, Kuran-1 Kerim öğreticisi ve öğrenci yurtlarında müdürlük gibi görevler yaptığ 1 Edirne ve İzmir'de günümüzde FETÖ olarak anılan örgütünün temelini atıp çekirdek kadrosunu oluşturmuştur. Kuruluş dönemi denilebilecek bu süreç, Gülen'in kendisini Türkiye'de dini bir lider olarak pazarlayıp başta bir kısım Nurcular olmak üzere dindar halkın desteğini yanına almayı başardığı bir süreçtir. İzmir 
Bornova merkez camiinde yaptığı vaazlar ve daha sonra özellikle 1977’den itibaren tüm ülke genelinde gerçekleştirdiği vaaz ve konferans turneleriyle Anadolu'da gündeme gelmiş ve kendisini kabul ettirmiştir. Bu dönem tüm Türkiye'de öğrenci evlerinin açıldığı az da olsa yurtların yapıldığı ilk dönemdir. İlk yurt da İzmir Bozyaka'daki yurttur. Daha sonra bu yurt koleje dönüşmüştür. Bu ilk dönem hem piramidin tabanının sağlama alınmasının hem de birinci katını inşa etmenin gerçekleştiği dönemdir. Bu yıllar aynı zamanda Gülen’in Üst Akıl/Büyük Akıl diye tanımlanan dış mihraklar ile de temas ettiği yıllardır. ( Polis Akademisi, 2018, s.15; Keleş,2017, s.71).

Özellikle eğitim amacıyla kırsaldan kente gelenlerin kalabileceği devlet yurtlarının olmaması ya da çok yetersiz olması, dini eğitim alma konusunda hassasiyeti olan kişilerin bu ihtiyaçlarının devlet eliyle uygun bir şekilde karşılanmaması/karşılanamaması, ekonomik alanda faizsiz bankacılık gibi inançları nedeniyle faizden uzak durmak isteyenlere yönelik devletin mekanizmalar vb. kurulmamıştır. FETÖ oluşan bu boşlukları çok iyi bir şekilde öğrenci yurtları, sınava hazırlık dersaneleri, öğrenci evleri, kitapevleri, yayınevleri, yardım kuruluşları, faizsiz finans kurumları vs. birçok farklı şekilde doldurarak kendini öğrenci yetiştiren eğitime, hizmete, yardıma adamış dini referanslı bir yapı gibi insanların gözünde kolayca meşruiyet kazanmıştır.

FETÖ’nün ortaya çıkışında siyasi istikrarsızlıkların, ülkenin eğitim, sağlık, kültür, dini eğitim vb. bir çok alanda ihtiyacı olan uzun vadeli planlamaların yapılmaması/yapılamaması, sınav sistemlerinde, eğitim müfredatlarında çok sık ve plansız değişikliklerin yapılması, katsayı adaletsizliği ile din eğitimi alanında önemli bir ihtiyaca karşılık veren İmam Hatip Liselerinin önünün kesilmesi gibi başka nedenlerin de etkili olduğu söylenebilir.

Vaaz kasetleri ve videolarıyla FETÖ örgütün endokrinasyon faaliyetlerine başlamıştır. " $B u$ endoktrinasyon örgüt liderinin kutsallaştırıldı̆̆ı on yılları kapsayan bir kültist radikalleşme sürecidir. Örgüte militan kazandırma faaliyetleri içerisinde, temel olarak 13-18 yaş arası çocukları hedef kitle olarak belirlemiştir. Nitekim çalışmanın ilerleyen bölümlerinde daha ayrıntılı biçimde bahsedileceği üzere 13-18 yaş arası döneminin çocukluk ile ergenlik arası geçiş dönemine denk gelmesinden dolayı çocukları etkilemek ve üzerlerinde psikolojik baskı kurarak onları radikalleştirmek daha kolay olmaktadır. Böylece bu hedef kitle üzerine yapılan çalışmalar sonucu terör örgütü insan kaynağı devşirme hususunda çok büyük bir başarı elde etmiştir" (Polis Akademisi, 2018, s.15).

FETÖ elebaşı; ikna ve inandırma faaliyetleri ile işe başlamış, ortaya çıtığı 1960’lı yıllardan 2000'li yıllara kadar sosyal adaletsizlik, eğitimsizlik ve din eğitiminin eksikliği temelinde kendine sosyal bir zemin bulabilmiştir. Siyasette ve devlet kurumlarında dindarların dışlanıp ötekileştirilmesi, Fetullah Gülen'in bu kesimden insanları kendi etrafında toplamasını kolaylaştırmıştır. Zira o, Müslüman bir âlim kisvesiyle vaazlarında Müslüman halkın din, iman, Kur'an gibi kutsallarını kullanmış, bunları bir propaganda vasıtası yaparak halkı yavaş yavaş etrafında toplamıştır. "FETÖ elebaşı bu hazırlık aşamasında etkili bir propaganda faaliyeti sürdürmüş; kendisi, müritleri ve bu yapılanmayı kullanan devletler tarafından örgütün 
reklaminin yapılması sonucu birey, toplum ve devlet üzerinde örgüte karşı olumlu bir algı oluşmuştur. Örgütün insan kaynağını yetiştiren FETÖ'ye ait okullar, dershaneler örgüt için önemli bir gelir kaynă̆ı olduğu kadar aynı zamanda örgütün en iyi reklam ve propaganda aracı olmuştur." (Karaman, 2018, s.110).

Fetullahçı Terör Örgütü görünüşte Müslümandı ve Türkçe konuşmaktaydı. Görünüşe göre hüküm veren Türkiye ve birçok ülke, Türkiyeli kimliğine bürünmüş FETÖ ve üyelerine herhangi bir engel çıkarmamıştır. 1960'lı yılların sonlarında çıkan ve karanlık yabancı eller tarafından büyütülen FETÖ işbirlikçileri; 'Türkçeyi yayıyoruz, ahlaklı ve dindar nesiller yetiştiriyoruz diye halkı yanıltarak devlet kurumlarına sızmaya başladılar. Özellikle 1980'den sonra farklı hükümetlerin desteğiyle güvenlik kuvvetleri, adliye, eğitim kurumları başta olmak üzere devletin değişik kurumlarında kendilerini gizleyerek yerleştiler. Paralel bir devlet yapılanması kurdular. Bin yll önce Ortadoğu'da terör estiren Hasan Sabbah'in fedaileri Haşhaşilere benzeyen FETÖ'cüler, 2007'den itibaren devleti tamamen ele geçirmek için harekete geçtiler (Yıldırım, 2016, s.25).

15 Temmuz Darbe girişimi öncesi algılarla vatandaşın gözünde eğitim, hayır, hizmet kurumu gibi kendini konumlandıran FETÖ aleyhine yayın yapılmasını çeşitli operasyonlarla engellemiş, yapılan yayınları da toplumda elde ettiği olumlu algıyla kolayca etkisiz hale getirmeyi başarmıştır.

15 Temmuz 2016 öncesi FETÖ ile ilgili yapılan yayınların büyük kısmı, ya kendi yazarlarınca veya değişik yöntemlerle kendi saflarına çekilen yazarlar tarafından kaleme alınan kitaplardır. Bu kitaplar ise adeta filin kulaklarını yelpaze gibi anlatmaktadır. Filin dişleri üzerine yazmaya çalışanlar çok az da olsa çıkmıştır. Filin dişlerini anlatan yazarlar örgüt tarafından çeşitli sıkıntılara maruz bırakılmıştır. Bu durum filin dişleri hakkında yazmak isteyenlere gözdağı vermiş ve caymalarına neden olmuştur. Bu tehdit, gözdağı ve caydırma ortamı 15 Temmuz sonrası devlet kadrolarındaki özellikle polis, asker ve adliyedeki tasfiyeler sayesinde sona ermiştir. Bu nedenle FETÖ ile ilgili yayınlarda 15 Temmuz sonrası tabiri caizse bir patlama olmuştur (Kuyaksil, 2018, s.16).

Ülkemizde FETÖ hakkında yukarda değinildiği üzere yapılan yayınlara bakıldığında örneğin, Türkiye'de dini hareketler konusunda referans olarak gösterilen Elisabeth Özdalga'nın Fetullah Gülen Hoca'nın liderliğindeki çağdaş Said Nursi taraftarlarını Sızıntı dergisindeki katı pozitivist metodolojiye dayll makro ve mikro konulara değinilmesinden, bilime sempatiyle bakmalarından dolayı oldukça olumlu bir şekilde nitelediği görülmektedir (Özdalga, 2007, s.39).

Özdalga’nın “İslamcılı̆̆ın Türkiye Seyri Sosyolojik Bir Perspektif” adlı eserinin Dördüncü Bölümü "Fethullah Gülen Hareketi Üzerine" ana başlı̆̆ında 'İslami Kalıba Dökülen Dünyevi Çilecilik: Fethullah Gülen' in Dindarlığı ve Eylemciliği', Fethullah Gülen Hareketinde Laikleşme Eğilimleri: Tıkanma mı, Yoksa Yenilenme Fırsatı mı?' ve 'Fethullah Gülen'in İzinde: Üç Kadın Öğretmenin Hayat Hikayesi’ başlıklarından oluşmaktadır. Özdalga bu makalelerinde örnek 
olarak; "Gülen okullarının amacı, yüksek kaliteli standart eğitim sunmaktır... Okullar ayrıca fen ve dil dilleri için laboratuvar araç gereçleri ve modern bilgisayar teknolojisini sağlar. Temel amaç, herhangi bir özel ideolojiyi aşılamadan öğrencilere iyi bir eğitim vermektir. Gülen müritleri arasındaki başlıca kanaat, ahlaki değerlerin, açıkça ikna ve dersler yoluyla değil gündelik tavırda iyi örnekler teşkil ederek yayılacağıdır" (2007, s.247) diyerek son derece olumlu bir bakış açısıyla baktığı görülmektedir. Diğer makalelerde de benzer şekilde bu hareketle ilgili ne kadar barış̧̧, hoşgörülü, ılımlı oldukları, modern bilimle çelişmedikleri vb. ifadelerle FETÖ sürekli yüceltilmiştir.

Ülkemizin sahip olduğu toplumsal bir zenginliği olarak hem laik hem de inançlarına sıkı sıkıya bağlı dindar hem de diğer inanç gruplarına hoşgörüyle bakan insanları barındırmasıdır. Ancak ülkemizdeki din ve siyaset tartışmalarının bir kısır döngü, fasit bir daire içinde dönmesinin başlıca nedeni, hakim seçkin kültürün, dindarlığı tam anlamıyla kavrayamaması, anlayamaması ve din alanında önemli bir bilgi boşluğunun ortaya çıkması yüzünden dini, laik siyasal düzene karşı bir tehdit olarak algilaması ve ondan korkması olduğu söylenebilir (Arslan, 2012, s.424; Kaya 2011, s.1). Bu bakış açısı dindar kesime karşı katı uygulamalara ve bu uygulamaların sonucu olarak da kontrol ve denetimden uzak yapıların ortaya çıkmasına zemin hazırlaması olmuştur.

Özellikle 15 Temmuz Darbe girişimi ve sonrasında yaşananlar bu ve benzeri yapıların nerelerden beslendikleri, nasıl bu seviyelere gelebildikleri, ortaya çıardıkları güvenlik zafiyetleri, ülkenin; dış politikasına, ekonomisine, eğitim sistemine, toplumsal güvene, dini değerlere, yardımlaşma ve paylaşma duygusuna vs. verdikleri zararın nasıl telafi edilebileceği konusunda birçok kamu kurumunun ve sivil toplum kurumunun, akademisyenlerin önemli çalışma alanlarından biri haline gelmiştir. Bu yaşanan olumsuzlukları gidermenin yanı sıra benzeri örgütlenmelerin önüne geçilebilmesi için özellikle kamu kurumlarının bu tür yapıların önünü açan boşlukları hızlıca doldurmalarının şart olduğu bu çalışmada referans olarak ele alacağımız Emniyet ve Diyanet Teşkilatının raporları gibi benzeri şekilde birçok rapor, akademik yayın ortaya çıkmıştır. Yapılan öneriler ve bu önerilerin uygulanma biçimleri, düzeyleri istenen seviyelerde olmasa da eskiye göre bu alanlarda bir farkındalık oluşturması bile son derece önem arz etmektedir.

\section{Emniyet Teşkilatının Hazirladığı “Yeni Nesil Terör: Fetö’nün Analizi” İsimli Raporun Analizi}

Çalışmamıza ilk olarak Emniyet Genel Müdürlüğü Polis Akademisi Başkanlığınca 2017 yılında hazırlanan "Yeni Nesil Terör: FETÖ’nün Analizi” Çalıştay Raporudur. Çalıştay Polis Akademisi başkan ve öğretim görevlilerinin moderatörlüğünde değişik kamu kurumlarından müsteşarlar, hakim, savcı, akademisyenden vs. oluşan yaklaşık 25 kişilik bir grupla gerçekleştirilmiştir.

Çalıstayın amacı Türkiye’nin yüz yüze kaldığı en önemli güvenlik, sosyo-ekonomik, sosyopolitik, sosyo-psikolojik sorunlarından bir tanesi olan FETÖ ile daha etkin bir biçimde mücadele edebilmek adına öncelikle onun yapısını ve eylem biçimlerini anlamanın önemli olduğu şeklinde ifade edilmiştir (Polis Akademisi, 2017, s.5). 
Çalıştayda öncelikle, FETÖ’nün üyelerini nasıl radikalleştirdiği bilimsel olarak ele alınmıştır. Örgütün üyeleri üzerinde kurduğu en açık hakimiyetin psikolojik kontrol yöntemi olduğu, bu hakimiyet sonucunda örgüt üyelerinin belirli bir radikalleşme sürecinden geçtikleri ve ortalama ahlaki değerlere sahip bir insanın yapamayacağı/yapmayacağı davranışları rahatlıkla yapabilir hale geldikleri öncelikle vurgulanmıştır. FETÖ, psikolojik kontrol üzerinden ödüllendirme ve cezalandırma yöntemini kullanarak, kutsal değer ve referanslarla grup normlarını benimseterek insanların, aile hayatlarından, ekonomik ilişkilerine kadar tüm hayatlarını denetim altına almıştır (Polis Akademisi, 2017, s.5).

FETÖ’nün gerek insan kaynağı sağlaması gerekse ekonomik gücünü artırması bakımından eğitim-öğretim faaliyetleri örgüt için çok önemli bir alan olmuştur. Bu sayede örgüt üyelerinin istenildiği gibi yetiştirilmeleri, öğrencilerin hedeflenilen kurumlara yerleşmesi sağlanmış ve de dershane, okul, eğitim-öğretim materyalleri sayesinde yılda milyarlarca liralık gelir elde edilmiştir. Dershanelerin kapatılması kararından sonra FETÖ’nün seçilmiş başbakana yönelik alenen terör faaliyetlerine giriştiği düşünüldüğünde eğitim-öğretim sektörünün örgüt açısından ne kadar önemli olduğu daha iyi anlaşılmaktadır. (Polis Akademisi, 2017, s.6). FETÖ’nün finansal kaynakları olarak ayrıca üyelerinin maaşlarından ve ticari işletmelerden kazandığı paraların yanında himmet adı alında iş adamlarından toplanan haraçlar, kamudan aktarılan paralar vs. sayılabilir.

Çalıştay raporu; Yönetici Özeti, FETÖ’nün Sosyo-Psikolojik Analizi, FETÖ’nün Dinî Anlayışı, Güvenlik Bürokrasisi ve FETÖ Yapılanması, FETÖ'nün Eğitim Alanındaki Yapılanması, FETÖ’nün Ekonomik Yapılanması, FETÖ’nün Devlete Sızma Mekanizması Olarak “Sınavlar”, FETÖ’ye Karşı Yürütülen Hukukî Mücadele, FETÖ’ye Karşı Yürütülen Siyasî ve İdarî Mücadele, Genel Değerlendirme ve Öneriler başlıkları olmak üzere on başlıktan oluşmaktadır. FETÖ’nün Sosyo-Psikolojik Analizi kısmında üyelerini 'Davranıssal ve Psikolojik Kontrol' olmak üzere iki yöntemi kullandığı ifade edilmiştir. Üyelerini radikalleştirmek için bireysel benlikleri yok ederek biz duygusunu üyelerine vermeye ve ailesi ve tüm sosyal çevreleriyle ilişkilerini keserek onlara normal standart bir ahlaka sahip bir bireyin asla yapamayacağ ş̧eyleri yapabilecek hale getirmeye çalışmaktadır. Örgütün bunu belli bir oranda başarmış olduğu maalesef 15 Temmuz gecesi çok açık bir şekilde ortaya çıkmıştır. (Polis Akademisi, 2017, s.8-9). FETÖ rüyalara ve İslam dinine ait kutsal ifadelere ve uygulamaları da önemli bir yönlendirici olarak sıklıkla kullanmaktadır. FETÖ’nün kullanmış olduğu söylem ve uygulamalara örnek olarak; FETÖ elebaşı Gülen'in Peygamber Efendimizle beraber evleri ziyaret etmesi, namaz sırasında Gülen için ayrı bir seccadenin serilmesi, bazı evlerde Gülen'in terliğinin olduğunun söylenmesi, ağabey ve ablalar tarafından gizlice terliklere gül suyu dökülerek gül suyu kokmaya başlayınca da evlere Gülen'in geldiğinin söylenmesi, rüyalarda görülen şeylerin kişilere doğrudan verilmesi gibi şeyler sayılabilir (Polis Akademisi, 2017, s.11). FETÖ görüldüğü üzere dini kavramları bile kendi çıkarları için istismar etmekten, fütursuzca kullanmaktan çekinmemiştir.

FETÖ’nün dini anlayışı başlı̆̆ında ise kendisinin terör faaliyetlerini din maskesi altında çok başarılı bir şekilde gizlediği ve üyelerini dini baskı altına alarak örgüt aleyhine konuşmanın, 
davranmanın çok büyük günah olduğuna inandırıldığı, sorgulamadan koşulsuz itaate zorladığının görüldüğü vurgulanmıştır (Polis Akademisi, 2017, s.15). Örgüt üyelerini sürekli dini değerleri istismar ederek, çarpıtarak, gelecekle ilgili kehanetlerle vs. kandırarak her türlü terör faaliyetini kolayca gerçekleştirebileceği bir zemin oluşturmuştur.

Örgüt elemanları Gülen'i bir Mehdi/Mesih (semavi dinleri de birleştirme misyonu olan) kabul ettikleri söylenebilir. Bu durum ise, "sahte mehdilik temelli bir radikalleşmeye" yol açmıştır. "Son Kurtarıcı" etrafında kenetlendiğini düşünen militanlar, kendilerini dış dünyadan tamamen koparmış ve çok uzun yıllar süren, sonunda da kitlesel katliam yapmayı bile onlar için "normalleştiren" bir radikalleşme sürecinden geçirilmişlerdir. (Polis Akademisi, 2017, s.18). FETÖ’nün üyelerini radikalleşme sürecinde dış dünyadan tamamen koparmasına örnek olarak evlerden televizyonların kaldırılması, sadece örgütün radyo, gazete, dergi ve internet hesaplarının takibinin sağlanması gibi yolları kullandığına çalıştığımız kurumlardaki örgüt mensupları aracillğıyla bizzat şahit olunmuştur. Örgüt üyelerini kendisine öyle bir bağlamış ve öyle bir mesaj bombardımanı alına almış istediği yasa dışı, insanlık dışı her şeyi 15 Temmuz Darbe girişiminde de görüldüğü üzere üyelerine kolayca yaptırabilmiştir.

Güvenlik Bürokrasisi ve FETÖ Yapılanması başlığında ise FETÖ militanlarının bürokrasinin bir özelliği olan içe dönük kadrolaşmacı ve klikleşme özelliğini kullanarak 1970'li yıllardan itibaren yavaşça ve sinsice bu alanda özellikle de güvenlik bürokrasisinde örgütlenmeye başladıkları ve zamanla büyük ölçüde de bu bürokratik yapıları ele geçirdikleri görülmüştür. "Ve bu örgütlenmede dị̧ "istihbarat servisleri" ile ilişki içerisinde "Gladio" tarzı bir örgütlenme olmuştur. Örgüt mensubu bu kişiler, esasında, diğer vesayetçi bürokratlar gibi, bir anlamda devleti kendileri olarak görmektedirler. Ayrıca Gladio hareketi bağlamında ise 15 Temmuz ve sonrasinda gerçekleşen senkronize saldırılar devletimizin gerçek ("uluslararası") vesayetçilerle ilk defa karşı karşıya geldiğini göstermektedir” (Polis Akademisi, 2017, s.20). FETÖ’nün kendini gizleyerek, takiyye yaparak devletin bürokratik kadrolarnna, özellikle güvenlik bürokrasisi içinde çoğunluğu ele geçirmeye çalıştığı ve bunu büyük oranda başardığı görülmektedir.

FETÖ’yü askeri darbeler özellikle 1980 darbesi, 28 Şubat Postmodern Darbesi vb. müdahaleler güçlendirmiştir. "1980 darbesi, FETÖ unsurlarının askeri liselerde ve harp okullarında, polis kolejlerinde ve Polis Akademisinde örgütlenmesinin yolunu açmıştır. 15 Temmuz sanık ifadelerinden anlaşılacağı üzere 1980'li yıllardan itibaren bu okullara girişs sinavları kontrol edilmeye başlanmıştır. "Mahrem Hizmetler İmamı"nın doğrudan kontrolü altında tedrisatından geçmiş olan subay ve polis amirleri FETÖ'nün en has militanlar olmuşlardır. Bu İmam'in tedrisatında radikalleşen 1980'li ve 1990'l yillarda mezun olan polis amirleri 17-25 Aralik'ı ve subaylar da 15 Temmuz darbe girişimini gerçekleştirmeye çalş̧mışlardır" (Polis Akademisi, 2017, s.21).

FETÖ’nün Eğitim Alanındaki Yapılanması başlı̆̆ında ise örgütün eğitim faaliyetlerine çok verdiği görülmüştür. Örgütün eğitime önem vermesinde üç önemli sebep vardır. Bunlardan birincisi, yurtiçi ve yurtdışı faaliyetleri için ihtiyaç duyduğu insan kaynağını eğitimle sağlamasıdır. İkincisi, eğitim faaliyetleri sayesinde hem yurtiçinde hem yurt dışında meşruiyet 
kazanması çok kolay olmuştur. Üçüncüsü, FETÖ bu eğitim faaliyetleri (Okullar, dersaneler, yayınevleri vs.) sayesinde çok büyük bir maddi gücü kontrol eder hale gelmiştir. (Polis Akademisi, 2017, s.25). Görüldüğü üzere eğitim hem yurtiçinde hem yurtdışında kendisini hayır işlerine adamış bir görünümle pazarlamasına, örgüt faaliyetleri için insan kaynağı teminine ve hepsinden daha önemlisi çok ciddi bir ekonomik gelir elde etmesine vesile olduğu için örgütün en önemli alanlarından birisi olmuştur. Özellikle dersanelerin kapatılması tartışmaları sürecinde hükümetle alenen mücadeleye girmekten çekinmemeleri eğitimin örgüt için ne kadar önemli olduğunun önemli göstergelerinden biri olarak değerlendirilebilir.

Örgütün Ekonomik Yapılanması başlı̆ı̆nda; örgütün, halk nezdine fazla bir tabanı olmayan fakat daha çok kamu kaynaklarılya beslenen bir yapı olduğu tespit edilmiştir. Bu sebeple, FETÖ'nün, geçmişte devletin kaynak tahsisatı yapan bütün finans mekanizmalarını kontrol etmeye çalıştığ görülmüştür. Bu kurumlar arasında TÜBİTAK, KOSGEB, Ulusal Ajans, SODES ve KÖYDES sayılabilir. Toplumda oluşturulan hizmet algısı ile de gönüllü ve gönülsüz toplanan himmetler de örgütün finans kaynaklarını oluşturmaktadır (Polis Akademisi, 2017, s.30). Örgüt özellikle eğitim ve ticari şirketler aracılı̆̆ılla banka, yayın şirketleri, madencilik şirketleri vs. birçok alanda da faaliyet göstererek ciddi bir ekonomik güce ulaşmıştır.

FETÖ’nün Devlete Sızma Mekanizması Olarak "Sınavlar" başlğı̆nda sınavların FETÖ tarafından devlete sızmak için çeşitli şekillerde ele geçirilerek kullanıldığı ifade edilmiştir. "FETÖ, devletin stratejik noktalarına adam devşirmek amacıyla soru hırsızlığı yapmış̧tr. Örgüt tarafindan, 2000-2013 yılları arasinda KPSS, ÖSS, ALES, Askeri Liseler, YDS sinavlarn gibi ÖSYM koordinatörlüğ̈̈nde yapılan tüm sınav soruları çalımııştır. Elde edilen sorular son derece stratejik olarak kullanılmıştır. Devletin istihdam politikası ve kamuoyu bu soruların nasıl kullanılacağın belirlemiştir. Örneğin ÖSS sınav sorularının tamamı yalnızca sınırlı sayıda sınav şampiyonu aday adayı ile paylaşılırken FETÖ dershanelerine sorular kısmen verilerek sınav sonuçlarının aşırı bozulması ve sorgulanmasının önüne geçilmiştir. FETÖ, dershanelerinde veya özel okullarında öğrenim gören öğrencileri "laik" ve "laik olmayanlar" şeklinde ikili bir ayrıma tutarak sinav soruların vermede iki farkl yöntem izlemiştir" (Polis Akademisi, 2017, s.32-33).

Fetö’ye Karşı Yürütülen Hukukî Mücadele başlığında ise Bylock'tan, Bank Asyayaya para yatırma, örgütün sendikalarına üye olma, üzerinden 1 dolar çıması gibi 16 kriterden oluşan bir mekanizma kullanılmakta olduğu ancak mücadelenin örgütün çok fazla sayıda kripto elemanı olması dolayısıyla çok daha kolay olmadığı vurgulanmaktadır (Polis Akademisi, 2017, s.36-38). FETÖ yapılan mücadeleyi sulandırmak için ise halen içerde olan kritpto elemanlarıyla örgütle bağı olmayan masum insanları da çeşitli yollarla (Bylock'la ilişkilendirme gibi) örgüt üyesi gibi göstererek yapılan mücadeleyi kamuoyu nezdinde itibarsızlaştırmaya çalışmaktadır. $\mathrm{Bu}$ nedenle mücadele sürecinde çok dikkatli olunması oldukça önem arz etmektedir.

Fetö’ye Karşı Yürütülen Siyasî Ve İdarî Mücadele başlığında kırk yıldan daha uzun bir süreden beri devletin tüm kılcal damarlarına sinsice sızıp devlet içinde ayrı bir devlet gibi paralel bir yapılanma oluşturan, üyelerini saklamak için her türlü hileye, takiyyeye başvurmaktan çekinmeyen ve gayesine ulaşmak için hiçbir ahlaki, hukuki kural tanımayan bu yapıyla 
mücadele etmek ne kadar zor olsa da bu mücadele Türkiye'nin bekası için oldukça önem arz etmektedir. Devletin bütün kurumlarına sızan bu yapıyla mücadele doğal olarak tek bir alan üzerinden yürütülemez. Örgütle mücadelede politik, ekonomik, bürokratik, hukuki, ekonomik, teolojik, sosyolojik ve psikolojik yönler ihmal edilmemelidir. (Polis Akademisi, 2017, s.39). Görüldüğü üzere FETÖ ile mücadelede tek bir alan üzerinden başarının mümkün olamayacağı, politik, ekonomik, sosyolojik, teolojik vs. kısaca hayatın her alanında topyekün bir mücadele ile ancak başarılı olacağı tespiti yapılmaktadır.

Genel Değerlendirme Ve Öneriler başlığında ise daha çok güvenlik bürokrasisi tarafından hazırlanmış olması nedeniyle olsa gerek FETÖ ile mücadelede daha çok polisiye, idari ve hukuki önerilerin yer aldığı görülen 18 madde öneri olarak sıralanmıştır. Öneriler olarak ise Örgütle yapılan mücadelede elde edilen bilgilerin bir merkezde toplanması, örgütün para kaynaklarının kesilmesi, örgütle mücadelede ihtisaslaşmış personele ihtiyaç duyulduğu, gizli tanıklık müssesesine dikkat edilmesi gerektiği gibi daha çok polisiye tedbirlerin sıralandığı görülmüştür (Polis Akademisi, 2017, s.42-44).

Örgütle mücadelede sıralanan önerilerde sadece son birkaç madde de psikolojik, sosyolojik, teolojik, toplumsal içerikli önerilere yer verildiği görülmüştür. Bu önerilerden birisi olan dini istismarını önlemek adına Diyanet teşkilatına düşen görevler şu şekilde ifade edilmektedir; “FETÖ para ve zenginlik, para ve makam dağıtıp, devlete alternatif olan bir sistem inşa etmeye çalışmakla birlikte, üyelerine ölümden sonraki hayatlarında cennete gideceklerine dair vaatler de vermektedir. Burada örgütün psikolojik öğelerin yanı sıra inançları kullanması durumu da söz konusudur. Cenneti vaat etmesi sonucunda gerçekleştirdiği tüm ahlaksızlıkları ve hukuksuzlukları meşrulaştıran FETÖ'nün (ki bu noktada DAEŞ’e benzemektedir) üyelerine her türlü eylemi yaptırabilme etkisi söz konusudur. Dolayısıla bu konuda Diyanet İşleri Başkanlı̆̆ına da önemli bir görev düşmektedir. Diyanet İşleri Başkanlı̆̆ı teolojik açıdan FETÖ ve

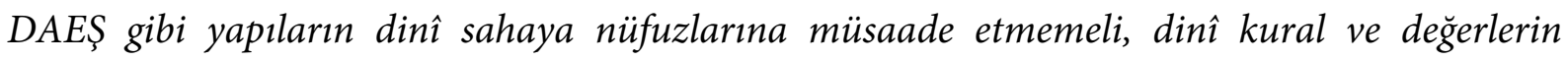
çarpıtılmasına karşı sistematik mücadele verilmeli ve dinin örgütler tarafindan araçsallaştırılmasının önüne geçmelidir. Ayrıca Diyanetin bu hususta alacağı rol ilerleyen dönemlerde din temelli radikalleşmenin de önüne geçecektir” (Polis Akademisi, 2017, s.45).

Dinin istismar edilmesini önlemek adına kamu kurumlarına, siyaset kurumuna düşen görevleri ise; katı laik uygulamaların dini grupların örgütlenmelerinin kapalı olmalarına neden olduğu ifade edilerek bu alanda yeni düzenlemeler yapılmasının şart olduğu ayrıca çok sıkı bir denetim mekanizmasının şart olduğu vurgulanmaktadır. Dini örgütlerin sadece dini alanda kalmaları bürokrasi içinde yapılanmalarına kesinlikle müsaade edilmemesi gerektiği ve yapılan mücadelenin dinsel bir mücadele olmadığı siyasal bir mücadele olduğu kamuoyuna çok iyi anlatılmalıdır. Son olarak devlet kademelerinde FETÖ'den boşalan yerlere başka grupların doldurmasına kesinlikle firsat verilmemelidir. (Polis Akademisi, 2017, s.45).

Yine kamu kurumlarının ihraçlar sonrası yaşanabilecek toplumsal kırılmalara, radikalleşme riskine karşı çalışmalar yapması gerekliliğinin ortaya çıktığı ifade edilmiştir. FETÖ ile mücadelede dikkat edilmesi gereken noktalardan biri de "FETÖ'yü doğuran iç ve dış etkenler 
olmaktadır. Katı laik politikalar ve devletin sosyal alanları boş bırakması, bu alanları doldurma konusunda FETÖ'ye ortam hazırlamıştır. Dış istihbarat örgütleri de bu alanları kullanarak FETÖ'yü Türkiye'ye karşı kullanmıştır. Bu konudaki iç ve diş etkenler çok iyi analiz edilmelidir" (Polis Akademisi, 2017, s.45-46) denilerek FETÖ vb. örgütlerin filizleneceği hiçbir boş alan bırakılmaması gerektiği bu durumun dış istihbarat örgütlerince kullanılarak iç işlerimize müdahalelere neden olabileceği ifade edilmiştir.

\section{Diyanet Teşkilatının Hazırladığı “Din İstismar Hareketi Fetö/Pdy Olağanüstü Din Şurası Kararları" İsimli Raporun Analizi}

15 Temmuz hain kalkışmasından çok kısa bir süre sonra Diyanet İşleri Başkanlığınca başta Cumhurbaşkanı Recep Tayyip Erdoğan, Meclis Başkanı İsmail Kahraman, Başbakan Yardımcısı Numan Kurtulmuş, Diyanet İşleri Başkanı Mehmet Görmez'in birer açış konuşması ile başlayan Olağanüstü Din Şurası düzenlenmiştir. Şuranın toplanma amacı; "Dini istismar eden bir örgüt (FETÖ/PDY) tarafindan 15 Temmuz 2016 gecesinde gerçekleştirilen kanlı darbe girişiminin ardından, ülke ve millet olarak içinden geçtiğimiz süreci değerlendirmek, bu ve benzeri yapıların ülkemize, milletimize ve dinimize verdiği zararları tespit etmek, dinî açıdan bu konularda istişarelerde bulunmak ve atılacak somut adımları belirlemek amacıyla ... olağanüstü toplamıştır" (Diyanet İşleri Başkanlığı, 2016, s.35) şeklinde ifade edilmiştir. Şura da FETÖ’nün dini nasıl istismar ettiği detaylı bir şekilde irdelenmiş, son bölümde özellikle benzer bir sıkıntıyla karşılaşmamak için neler yapılacağı konusunda önerilere yer verilmiştir. Şura önce açıs konuşmaları ve son olarak Şura kararları ve Açılamalar bölümüyle sona ermektedir.

Şura da toplam 20 maddeden oluşan ve çoğunluğu FETÖ'nün dini nasıl istismar ettiğini ortaya koyan ifadeler yer almaktadır. Şura kararlarının ilk 14 maddesi daha çok dinin nasıl istismar edildiği, dinin nasıl içinin boşaltıldığı gibi konulara ağırlık verildiği görülmektedir. Dolayısıyla bu maddelere değinilmeden son 6 madde de özellikle FETÖ vb. yapıların ortaya çıkmasına zemin hazırlayan nedenler ve bunlarla mücadele konusundaki önerilere daha fazla değinilecektir. Şura kararları;

- FETÖ’nün dini istismar faaliyetleriyle ilgili bilimsel çalışmaların kaçınılmaz olduğu şöyle ifade edilmektedir; "Diyanet ve İlahiyat camiasinin FETÖ ve benzer yapilarin dini istismar faaliyetlerini irdeleyen ilmî çalş̧malar yapmaları aciliyet kesbetmektedir. Bu bağlamda örgütü ve liderini yüceltici sözde bilimsel çalş̧alar ve yayınlar da ilgili kurumlarca incelenerek bilimsel açıdan değerlendirilmeli ve gereği yapılmalıdır" (Diyanet İşleri Başkanlığı, 2016, s.71).

- Diyanetin bir üst kurul kurarak FETÖ'nün İslam’a verdiği zararların tespit edilerek yapılan tahrifatın düzeltilmesi için gerekli olduğu vurgulanmıştır. "Din İ̧sleri Yüksek Kurulu bünyesinde, İlahiyat Fakültelerindeki farklı branşlardan akademisyenlerin de iştirakiyle özel bir komisyon oluşturulacaktır. Bu komisyon, öncelikle FETÖ/PDY terör örgütünün İslam'a ve Müslümanlara verdiği zararları, İslam'in inanç ilkeleri, ibadet telakkisi ve ahlak düsturlarında yaptığı tahrifat ve tahribatı, İslam'in temel kavramlarına dair çarpıtmaları tespit edilecek ve bu tespitler kamuoyu ile paylaşılacaktır" (Diyanet İşleri Başkanlığı, 2016, s.71). 
- FETÖ ve benzeri yapıların tekrar ortaya çıkmaması için başta eğitim alanında özellikle din eğitiminde atılması gereken adımların ivedilikle atılması gereği ifade edilmiştir. “ $B u$ tür dinî yapıların toplumu bir kez daha aldatmasına firsat vermemek için, din eğitim ve öğretim politikaları yeniden değerlendirilmeli ve bu çerçevede her seviyede din eğitimi ve öğretimi gözden geçirilmelidir” (Diyanet İşleri Başkanlı̆̆ı, 2016, s.72).

- Dini yapılara aşırılıklara kaçmamaları, şeffaf olmaları, denetime açık olmaları şartıyla izin verilmesinin bu tür yapıların yer altına inmesini ve kontrollü bir şekilde varlıklarını devam ettirmelerinin sağlanmasının daha sağlıklı sonuçlar doğuracağı vurgulanmıştır. "Diyanet İşleri Başkanlı̆̆l, özellikle Din İşleri Yüksek Kurulu marifetiyle özgürlüklerine müdahale edilmeksizin Türkiye'de din hizmetine ve din eğitimine destek veren sivil din̂े-sosyal teşekküllerle, İslam'in tarih boyunca medeniyetler kuran ana yolundan ayrlmamak, her türlü ifrat ve tefritten uzak kalmak, daha şeffaf ve denetlenebilir yapılar olmak yönünde ortak çalışmalar yapılmalıdır. Ayrıca dinî ve ilmî denetim ve rehberlik için Diyanet İșleri Başkanliğı bünyesinde üst kurullar oluşturulmalıdır" (Diyanet İşleri Başkanlığı, 2016, s.74).

- Katı laik uygulamaların din-devlet ilişkisini sağlıksız bir zemine oturttuğu ve bu durumun da zaman zaman istenmeyen durumlara neden olduğu vurgulanarak bu alanda yeni bir bakış açısıyla bu tür istismar alanlarını yok edecek yasal zeminin hazırlanmasının faydalı olacağına değinilmiştir. "Cumhuriyet tarihi boyunca din-devlet-toplum arasında yaşanan sosyo-politik gerilim süreçlerinde ülkemize özgü bir kurumsallaşmanın yeterli düzeyde ve eş zamanlı olarak gerçekleştirilememesi nedeniyle ortaya çıkan boşlukta türeyen din eksenli yapılar, zaman zaman toplumun dinî hayatımı zaafa uğratacak boyutlara ulaşmıştır. Bu durum, ülkemizde din-devlet-toplum ilişkilerinin gerekli yasal zeminin inşası da dâhil olmak üzere yeniden ele alınmasını zorunlu kılmaktadır” (Diyanet İşleri Başkanlığı, 2016, s.76).

- FETÖ’nün dine verdiği zararların özellikle genç nesillere verdiği zararların tespit ve bertaraf edilmesi için çalışmalar yapılması kararlaştırılmıştır. "Dini ve maneviyatı kirletmekten kaçınmayan bu hain saldırı neticesinde pek çok vatandaşımızın bilhassa genç nesillerin maneviyatını derin bir bunalım ve çıkmaza sürükleme potansiyelini bertaraf etmek için özel çalışmalar yapılacak ve yayınlar gerçekleştirilecektir” (Diyanet İşleri Başkanlığı, 2016, s.78).

\section{Sonuç ve Değerlendirme}

Diyanet Teşkilatının din hizmetleriyle ilgili bir kurum olmasıyla tespitlerinin ve önerilerinin büyük bir çoğunluğunun dini içerikte olması gayet doğaldır. Fakat Diyanet ve Milli Eğitim Bakanlığı, Gençlik ve Spor Bakanlığı, Kredi Yurtlar Kurumu vb. birçok kurum üzerlerine düşen sorumlulukları özellikle 15 Temmuz öncesi döneme kadar çok fazla yerine getiremedikleri/getirmedikleri FETÖ gibi bir örgütün palazlanmasından çok rahat bir şekilde anlaşılabilir. Bu durumun tespitini hem Emniyetin raporunda hem Diyanetin raporlarında da zaten ifade edildiğini görülmektedir.

Sıralanan maddelere bakıldı̆̆ında FETÖ ve benzeri yapıların dini istismar faaliyetlerinin bilimsel olarak incelenmesi ve bunları önleyici bilimsel çalışmaların yapılması gerektiği vurgulanmıştır. Bu öneri benzer şekilde Polis Akademisince hazırlanan raporda da vurgulanmıştır. Diyanet ve diğer kamu kurumları ve sivil toplum kuruluşlarınca çeşitli raporlar, 
broşürler, akademisyenler tarafından çeşitli bilimsel çalışmalar yapılsa da bu alanda yapılan çalışmaların yeterli düzeyde olduğunu söylemek mümkün değildir.

Öneriler olarak FETÖ ve benzeri dinî yapıların toplumu tekrar aldatmasına firsat vermemek için, din eğitim ve öğretim politikaları yeniden değerlendirilmeli ve bu çerçevede her seviyede din eğitimi ve öğretimi gözden geçirilmelidir tespitine yer verilmiş ve bu tespit çok büyük oranda doğru bir tespittir. Bu konuda benzer önerinin Polis Akademisi Başkanlığınca hazırlanan raporda zikredilmesi oldukça önemlidir. Son birkaç eğitim-öğretim yılı müfredatlarında Seçmeli olarak Kuran-ı Kerim, Hz. Peygamberin Hayatı, Temel Dini Bilgiler gibi derslerin yer almaya başlaması, İmam-Hatip Liselerinin nicelik ve nitelik olarak geliştirilmesi, Diyanetin yaz kurslarını eskiye oranla daha dolu içeriklerle daha etkin bir şekilde gerçekleştirmesi, yine Diyanetin uygun olan Camilerde ya da farklı mekanlarda 4-6 yaş anaokulları açması, Diyanet TV. ve radyolarının faaliyete geçmesi olumlu adımlar olarak sayılabilir. Ancak bu adımların da bu alandaki ihtiyaçları tam olarak karşıladığı söylenemez.

Yine lise ve özellikle üniversite öğrencilerinin konaklama imkanlarının Kredi Yurtlar Kurumunun yurt kapasitesinin artırılarak geliştirilmesi, burs ve kredi imkanlarının artırılması FETÖ ve benzeri yapıların istismar alanlarını ortadan kaldırma konusunda oldukça önemli adımlar olmakla birlikte halen bu alanlarda eksiklikler olduğu söylenebilir.

FETÖ’nün en güçlü olduğu eğitim alanıyla ilgili olarak dersanelerin kapatılması sonucu kurs ve etüd merkezi şeklinde tabela değişikliğiyle dersanelerin devam ettiği, bu eğitim-öğretim yılı sonunda kurs ve etüd merkezlerinin kapatılacağ daha kapatılmayacağını beyan ederek öğrenci kaydetmeye devam ettikleri öğrencilerimiz ve velilerimizce tarafımıza iletilmektedir. Bu mücadeleyi zaafa uğratmamak adına bu tür kurumlara kesinlikle taviz verilmeden kapatılmaları gerekmektedir. Ancak bunu yaparken bu kurumların yerine getirdiği işlevi okulların, halk eğitim merkezlerinin takviye kurslarıyla bu boşluğu doldurmaları şarttır. Fakat uygulamaya bakıldığında birçok okulda kursların açılması merkezi yönetim tarafından istense de idarecilerin kendilerine iş yükü getirmesi nedeniyle ya da başka nedenlerle bu kursları açmak istememekte ve öğrenci ve veliler bu tür yapıların insafina terk edilmektedir.

Okulların sadece akademik kurslar değil spor, sanat, kültürel etkinliklerin yapıldığı öğrencilerin bir bütün olarak kendilerini geliştirebildikleri, yetiştirebilecekleri, ortamlar olarak işlev görmesi son derece önemlidir. Sadece okul zamanı değil yaz tatillerinde de çalışan anne ve babaların çocuklarının güvenli ortamlarda yukarda sayılan etkinliklere katılabilmesi için tüm okulların öncelikle tüm gün eğitime geçirilmesi ve ders saatleri sonrası akşam saatlerine kadar ve Cumartesi günleri de akademik, sportif, sosyal, kültürel, dini kısaca ihtiyaç duyulan tüm alanlarda aktif faaliyetler düzenlemelidirler. Aksi taktirde aileler çocuklarına başka dini örgütlenmelerin, yapılanmaların yada maddi imkanlarını çok zorlayan özel kursların eline düşmekten kendilerini koruyamayacaklardır. Bu okullarda düzenlenecek etkinlikler için okul yönetimlerince istenen seviye yakalanamıyorsa Halk Eğitim Müdürlükleri devreye sokularak bu sorunun çözülmesi sağlanmalıdır. 
Cumhuriyetin kuruluşuyla din-devlet ilişkilerinde ortaya çıkan ayrışma sonucu bu alanda ciddi kırılmalar yaşanmıştır. 19. madde de bu kırılmanın ülkemizde din-devlet-toplum ilişkilerinin gerekli yasal zeminin inşası da dâhil olmak üzere yeniden ele alınmasını zorunlu kılmakta olduğu vurgulanmaktadır. Aynı öneri Polis Akademisince hazırlanan rapor da FETÖ benzeri örgütlerin önüne geçilebilmesi için kapalı bir örgüt görünümünde olan bu yapılanmaların kontrolü adına Tekke ve Zaviyeler Kanunu yeniden gözden geçirilmesi gerektiği şeklinde karşımıza çıkmaktadır. Ayrıca dinî örgütlenmelerin dinî sahada tutularak bunların bürokraside yapılanmalarının önüne geçilmesi ve FETÖ’ den boşalan yerlere göz diken başka örgütlenmelere asla izin verilmemesi gerektiği vurgulanmaktadır. Kamuoyunda FETÖ benzeri örgütlerin bazı kamu kurumlarında etkin olmaya başladığı söylentileri üzerine gidilmeli varsa bu tür durumlar derhal müdahale edilmelidir.

FETÖ benzeri örgütlerin var olan boşlukları doldurmasına firsat verilmemeli, bu alanlar öncelikle Milli Eğitim Bakanlığı, Gençlik ve Spor Bakanlığı, Diyanet İşleri Başkanlığı, Kredi Yurtlar Kurumu vb. kurumlarla gençlerin her türlü eğitimsel, psikolojik, sosyolojik, dini ihtiyaçları karşılanmalıdır. Var olan dini yapılanmaların çok ciddi bir şekilde denetlenmeleri, gelir-giderlerinin, faaliyetlerinin şeffaf bir şekilde kamuoyuyla paylaşılması sağlanmalıdır.

Her eğitim kademesinde ihtiyaç duyulan dini eğitim okullarda isteyen tüm öğrencilere verilmeli bu konunun FETÖ benzeri örgütlerin istismar alanı olmaktan çıkarılması sağlanmalıdır. Yine özellikle ortaokul, lise ve üniversite öğrencilerinin ihtiyaç duyabilecekleri yurtlar çok iyi bir şekilde planlanmalı, devlet yurtlarının sayısı ve kalitesi artırılarak öğrencilerin ve ailelerin farklı arayışlara girmelerine ihtiyaç kalmamalıdır. Çalıştığımız ortaöğretim kurumundan en az 30-40 öğrenci dini eğitim, daha disiplinli çalışma ortamı vb. gerekçelerle evleri merkezde olmasına rağmen farklı yapıların yurtlarında kalmaktadır. Bu konu da böyle bir ihtiyaç varsa devlet daha sağlıklı koşullarda bu ihtiyacı karşılamalı yeni FETÖ’lerin ortaya çıkmasına asla fırsat verilmemelidir.

FETÖ’nün bir nesilde yarattığı dini ve manevi kirliliğe yönelik olarak çeşitli çalışmalar yapılacağı bu insanların bu çıkmazdan kurtulmalarının sağlanacağı ifade edilmektedir. Polis Akademisince hazırlanan raporda da aynı şekilde FETÖ’nün dini anlamda yaptığı tahribatın araştırılıp, giderilmesi yönünde çalışmaların yapılması ve bu konuyla ilgili olarak da öncelikle Diyanet teşkilatının ilgilenmesi ifade edilmektedir. Ancak bu konuyla ilgili de sınırlı sayıda rapor, broşür hazırlamaktan öte çalışmaların olduğunu söylemek pek mümkün gözükmemektedir. Bu konularda yazılı, görsel, internet medyası, sosyal medya vs. tüm kanallar aktif kullanılarak FETÖ'nün insanların zihninde bıraktığı kötü tohumların yeşermeden yok edilmesi sağlanmalı ve daha da önemlisi yeni FETÖ’lerin ortaya çıkmasını önleyecek aktif bir çalışma özellikle dini alanda yürütülmelidir.

İhraçlar sonrası FETÖ üyelerinin kendilerinin ve ailelerinin radikalleşmelerini önlemek ve toplumla entegrasyonlarını sağlamanın önemine hem Polis Akademisi hem Diyanet hazırladıkları raporlarda değinmektedirler. Diyanet raporunda dini ve maneviyatı kirletmekten kaçınmayan FETÖ’nün bilhassa genç nesillerin maneviyatını derin bir bunalım ve çıkmaza 
sürüklediği bu durumu bertaraf etmek için özel çalışmaların yapılacağı ve yayınlar gerçekleştirileceği ifade edilmesine rağmen bu konuda yapılan çalışmaların çok gözle görülür elle tutulur, somut projelere dönüşmediği görülmektedir. Özellikle karı-koca birden ihraç olan sosyo-ekonomik olarak çok ciddi bir kayıp yaşayan bireylerin topluma yeniden kazandırılmaları, radikalleşmelerini önleyecek her bölgeye, her ile özgü mekanizmaların kurulması, iş hayatından tamamen dışlamak yerine devlet ve toplum adına kazanmaya yönelik fırsatlar sunulmalıdır. Aksi taktirde kökü dışarıda olan bu örgüt gelecekle ilgili ümidini yitiren bu üyelerini kolaylıkla tekrar kötü emelleri için kullanma konusunda zorlanmayacaktır.

Son olarak FETÖ ile mücadele hukuki ve idari yönden büyük oranda kazanılmış gibi görünse de asıl mücadelenin psikolojik, sosyolojik, dini vb. boyutlarıyla tam anlamıyla kazanılması için önümüzde daha uzun bir yol olduğu her gün yapılan operasyonlarla ortaya çıan kripto üyelerin varlığından anlaşılabilir. Bu nedenle mücadelenin bu alanlarda yoğunlaştırılmasının daha faydalı olacağı söylenebilir.

\section{Kaynakça}

Arslan, H. (2012). Dini Gruplar ve Siyaset YENİ ASYA. Ankara: Ankara Okulu.

Ayık, H. (2016). Din - Devlet İlişkileri Bağlamında İslâmî Cemaatlerin Devletle İlişkileri Üzerine. Artvin Çoruh Üniversitesi Uluslararası Sosyal Bilimler Dergisi, 2(1), 62-77. https://doi.org/10.22466/acusbd.263585

Diyanet İşleri Başkanlığı, (2016). Din İstismar Hareketi FETÖ/PDY Olağanüstü Din Şurası Kararları. Ankara: Diyanet Vakfı.

Duman, M.Z. (2010). Türkiye'de Laiklik Sorununun Siyasal Temelleri. Uluslararası İnsan Bilimleri Dergisi, 7(2), 284-303.

Habermas, J. (2006). Religion in the Public Sphere. European Journal of Philosophy, 14(1), 125. $\quad$ https://onlinelibrary.wiley.com/doi/epdf/10.1111/j.1468-0378.2006.00241.x (E.T.08/05/2019)

Karaman, G. (2018). 15 Temmuz’a Giden Süreç ve FETÖ Üzerine Düşünceler. Akademik Sosyal Araştırmalar Dergisi, 6(71), 107-118.

Kaya, K. (2011). Akademisyenlerin Gözüyle Türkiye’de Din-Siyaset İlişkisi. Isparta: Fakülte.

Keleş, A. (2017). Fetö’nün Kronolojik Analizi, Eskiyeni, Anadolu İlahiyat Akademisi Araştırma Dergisi, 34, 69-73.

Kuyaksil, A. (2018). Fetullahçı Terör Örgütü Gerçeği. Ankara: Orion.

Mardin, Ş. (2012). 19. ve 20. Yüzyillarda Osmanlida ve Türkiye'de İslam Türkiye, İslam ve Sekülarizm, İstanbul: İletişim.

Özdalga, E. (2007). İslamcıllğın Türkiye Seyri Sosyolojik Bir Perspektif. Gamze Türkoğlu (Çev.) 2. Baskı. İstanbul: İletişim. 
Sarıkaya, M.S. (2000). Cumhuriyet Dönemi Türkiye'sinde Dini Tarikat ve Cemaatleri Toplumdaki Yeri. Süleyman Demirel Üniversitesi Fen- Edebiyat Fakültesi Sosyal Bilimler Dergisi, 3, 93-102.

Polis Akademisi, (2017). Yeni Nesil Terör: FETÖ’nün Analizi FETÖ, Çalıştay Raporu No.10. Ankara: Polis Akademisi.

Polis Akademisi, (2018). Uluslararası Bir Tehdit Olarak FETÖ. II. Uluslar arası Güvenlik Sempozyumu Raporu No.20, Ankara: Polis Akademisi.

Tunç A., Atılgan A. (2018). Paralel Devlet Yapılanmasının (PDY) Kamu Kurumlarına Sirayeti ve Bürokratik Vesayet Darbesi, Kahraman Maraş Sütçü İmam Üniversitesi Sosyal Bilimler Dergisi, 15 Temmuz ve Türkiye Demokrasisi Özel Sayıs1, 15, 76-104.

Yıldırım, B. (2016). 65. Hükümet Programı, Ankara: Türkiye Cumhuriyeti Başbakanlık. 